\title{
Pengembangan UMKM Digital di Masa Pandemi Covid-19
}

\author{
Lathifah Hanim $^{(1)}$, Eko Soponyono ${ }^{(1)}$, Maryanto ${ }^{(1)}$ \\ Universitas Islam Sultan Agung \\ lathifah.hanim@yahoo.co.id.
}

\begin{abstract}
Abstrak.
Teknologi saat ini terus berkembang dan manfaat penggunaan internet terasa bagi parasaha para pemakainya. Beberapa orang merasa ketergantungan dengan adanya internet, termasuk aktivitas Usaha Mikro Kecil dan Menengah (UMKM) dalam memanfaatkan teknologi informasi untuk menjalankan usahanya khususnya di masa pandemi Covid-19. Metode Penelitannya adalah yuridis empiris, dengan teknik pengambilan data berupa studi pustaka dan wawancara. 1). Pengembangan UMKM digital di masa pandemi covid-19 di Jawa Tengah yaitu dengan adanya skema pengembangan UMKM digital dapat menjadi salah satu alternatif menyelamatkan pelaku usaha di tengah pandemi Covid-19. Pengembangan UMKM berbasis digital menjadi salah satu alternatif penyelamatan sektor UMKM di masa pandemi Covid-19.2).Dampak dan solusi dari pengembangan UMKM digital di masa pandemi Covid-19 di Jawa Tengah adalah Banyak UMKM yang mengalami berbagai permasalahan seperti penurunan penjualan, permodalan, distribusi terhambat, kesulitan bahan baku, produksi menurun dan terjadinya banyak pemutusan hubungan kerja untuk pekerja dan buruh yang kemudian menjadi ancaman bagi perekonomian nasional. Solusinya perlu adanya inovasi dan kreatifitas dari pelaku UMKM agar usahanya dapat terus bertahan dan berkembang dengan model kewirausahaan digital akan mendorong terciptanya inovasi baru sehingga dapat menciptakan ekosistem baru bagi UMKM yang bisa meningkatkan produktivitas dan kesejahteraan rakyat Indonesia. Selain itu dengan teknik ini para pelaku UMKM akan terus bermotivasi memanfaatkan teknologi dalam jaringan untuk memasarkan produknya.
\end{abstract}

Kata kunci: UMKM Digital, Covid-19, Jawa Tengah..

\begin{abstract}
.
Today's technology continues to grow and the benefits of using the internet are felt for its users. Some people feel dependent on the internet, including the activities of Micro, Small and Medium Enterprises (MSMEs) in utilizing information technology to run their business, especially during the Covid-19 pandemic. The formulation of the problem is 1). How is the development of digital MSMEs during the COVID-19 pandemic in Central Java? What are the impacts and solutions for the development of digital MSMEs during the Covid19 pandemic in Central Java? The research method is empirical juridical, with data collection techniques in the form of literature studies and interviews. 1). The development of digital MSMEs during the COVID-19 pandemic in Central Java, namely the existence of a digital MSME development scheme, can be an alternative to saving business actors in the midst of the Covid-19 pandemic. The development of digital-based MSMEs is an alternative to saving the MSME sector during the Covid-19 pandemic. 2). The impact and solutions of developing digital MSMEs during the Covid-19 pandemic in Central Java is that many MSMEs are experiencing various problems such as decreased sales, capital, hampered distribution. , the difficulty of raw materials, decreased production and the occurrence of many layoffs for workers and laborers which later became a threat to the national economy. The solution requires innovation and creativity from MSME actors so that their business can continue to survive and develop with a digital entrepreneurship model that will encourage the creation of new innovations so as to create a new ecosystem for MSMEs that can increase the productivity and welfare of the Indonesian people. In addition, with this technique, MSME actors will continue to be motivated to use technology in the network to market their products.
\end{abstract}

Keywords: Tourism Development Concept, Tourism Development Efforts, Government Assets. 


\section{PENDAHULUAN}

UMKM merupakan kegiatan usaha yang mampu memperluas lapangan kerja dan memberikan pelayanan ekonomi secara luas kepada masyarakat dan dapat berperan dalam proses pemerataan dan peningkatan pendapatan masyarakat, mendorong pertumbuhan ekonomi dan berperan dalam mewujudkan stabilitas nasional. Selain itu, UMKM adalah salah satu pilar utama ekonomi nasional yang harus memperolah kesempatan utama, dukungan, perlindungan dan pengembangan seluas-luasnya sebagai wujud keberpihakan yang tegas kepada kelompok usaha ekonomi rakyat, tanpa mengabaikan peranan Usaha Besar dan Badan Usaha Milik Negara.

Di Indonesia, hampir semua sektor mengalami dampak terutama ekosistem ekonomi yang selama ini telah mejadi tumpuan masyarakat. Pandemi Covid-19 telah membuat terjadinya pelambatan sektor ekonomi di Indonesia dengan berbagai turunannya. Sektor Usaha Mikro Kecil dan Menengah (UMKM) yang merupakan bagian terpenting dari sektor ekonomi sangat merasakan dampaknya. Banyak UMKM yang mengalami berbagai permasalahan seperti penurunan penjualan, permodalan, distribusi terhambat, kesulitan bahan bak, produksi menurun dan terjadinya banyak pemutusan hubungan kerja untuk pekerja dan buruh yang kemudian menjadi ancaman bagi perekonomian nasional. UMKM sebagai penggerak ekonomi domestik dan penyerap tenaga kerja tengah menghadapi penurunan produktivitas yang berakibat pada penurunan profit secara signifikan. Pandemi Covid-19 telah membuat menurunnya daya beli masyarakat, salah satunya dikarenakan publik telah mengurangi interaksi diluar ruangan untuk menekan persebaran pandemi. Dengan demikian, banyak konsumen yang kemudian menjaga jarak dan mengalihkan pembelian secara digital.

Saat ini interaksi antar manusia telah melalui teknologi, secara tidak langsung semua proses yang dulunya dilakukan secra konvensional sekarang mulai beralih ke digital. Hal ini merupakan salah satu efek dari adanya revolusi industri 4.0. Dampak era revolusi industri 4.0 adalah teknologi digital yang digunakan memungkinkan terjadinya intekoneksi antara mesin fisik dengan sistem produksi teknologi menjadi unsur utama terhadap pengembangan industri konvensional menuju industri digital sehingga mampu mentransfer data tanpa bantuan manusia serta dengan adanya big data agar mampu membantu dalam menentukan arah dalam bisnis (Rosita, 2020).

Penggunaan media digital potensial untuk memperkaya dan menawarkan kesempatan untuk belajar dan melakukan literasi dengan mudah. Menggunakan media digital memungkinkan sasaran untuk menggunakan, aktif, membangun kedekatan dan mendorong kemampuan untuk belajar. Akan ada banyak manfaat yang dapat di rasakan jika UMKM mampu untuk menguatkan ranah digital. Teknologi informasi memiliki sejumlah keuntungan diantaranya memberikan peluang memperluas akses pasar, sebagai media pemasaran dan masih banyak lagi (Kervin, 2016).

Hadirnya Teknologi Informasi (TI) mengubah cara dalam bisnis dengan memberikan peluang dan tantangan baru yang berbeda dengan cara konversional. TI merupakan salah satu pilar utama pembangunan peradaban manusia saat ini yang harus mampu memberi nilai tambah bagi masyarakat luas. Pelaku bisnis di Indonesia semakin menyadari kekuatan internet dan perangkat digital dalam peningkatan kerja usahanya (elloite, 2016).

Dampaknya banyak pelaku usaha UMKM yang harus menutup usahanya karena menurunnya pembelian dan masih tergantung pada penjualan secara luar jaringan (offline). Sehingga beberapa sektor UMKM yang belum beradaptasi secara digital pada akhirnya sangat terdampak hingga menutup gerainya. Pandemi Covid- 
19 secara tidak langsung telah mendorong perubahan baru dalam langgam bisnis Indonesia. Perubahan tersebut diantaranya yaitu beralihnya bisnis offline menuju bisnis digital yang dikenal juga fenomena kewirausahaan digital. Berdasarkan pada uraian tersebut diatas, Peneliti tertarik untuk mengkajinya,yaitu dengan melakukan penelitian yang berjudul " Pengembangan UMKM Digital di Masa Pandemi Covid$19 ”$.

\section{METODE PENELITIAN}

Menurut Setiono, ada 5 (lima) konsep hukum, yaitu: Pertama, Hukum adalah asas kebenaran dan keadilan yang bersifat kodrati dan berlaku universal; Kedua, Hukum adalah norma- norma positif di dalam sistem perundang-undangan hukum nasional; Ketiga, hukum adalah apa yang diputuskan oleh hakim inconcreto, dan tersistematisasi sebagai judge made law;Keempat, Hukum adalah pola-pola perilaku sosial yang terlembagakan, eksis sebagai variabel sosial yang empirik; Kelima, Hukum adalah manifestasi maknamakna simbolik para perilaku sosial sebagai tampak dalam interaksi antar mereka (setiono, 2010) . Penelitian ini mendasarkan pada penelitian hukum yang dilakukan dengan pendekatan doctrinal dan non doctrinal. Penelitian ini juga mendasarkan pada konsep legal positivis yang mengemukakan bahwa norma hukum identik dengan norma-norma yang tertulis dan dibuat serta diundangkan oleh lembaga negara yang berwenang (Rony, 1990) . Penelitian ini menggunakan metode kualitatif.

Sumber dan jenis data meliputi 2 (dua) sumber, yaitu: 1) Data Primer. Yaitu data yang diperoleh langsung dari sumber utama yang berwujud pandangan, pemikiran, aspirasi, tindakan-tindakan, peristiwa-peristiwa dan hubungan-hubungan hukum dan kata-kata (Lexy 1998). Jenis data ini memberikan keterangan atau informasi secara langsung mengenai segala sesuatu yang berkaitan dengan objek penelitian, dimana diperoleh langsung melalui lapangan berupa kata-kata dan tindakan dengan cara wawancara mendalam (indepth interview). Wawancara dilakukan dengan: Pelaku Usaha UMKM Jawa Tengah, Dinas Koperasi UKM Jawa Tengah, konsumen, akademisi, dan praktisi. Dan . Focus Group Discussion (FGD). 2) Data Sekunder. Jenis data yang dipakai dalam pendekatan doctrinal adalah data sekunder, apabila dilihat dari segi informasi yang diberikan maka bahan pustaka dapat dibagi dalam 3 (tiga) kelompok, sebagai berikut: a) Bahan Hukum Primer, yaitu bahan hukum yang mempunyai kekuatan mengikat secara yuridis. Bahan hukum primer dalam penelitian ini mencakup:UUDN RI Tahun 1945, KUHPerdata, Undang-Undang No. 20 Tahun 2008 tentang Usaha Mikro, Kecil dan Menengah dan Peraturan Pemerintah No. 7 Tahun 2021 tentang Kemudahan, Pelindungan, dan Pemberdayaan Koperasi dan Usaha Mikro, Kecil dan Menengah. b) Bahan hukum sekunder, yaitu bahan pustaka yang berisi informasi tentang bahan primer. Adapun yang digunakan dalam penelitian ini meliputi buku, literatur, skripsi, tesis, disertasi, makalah, laporan penelitian, internet dan sebagainya yang berkaitan dengan UMKM. c) Bahan hukum tersier, yaitu bahan yang memberikan petunjuk maupun penjelasan terhadap bahan hukum primer dan sekunder yaitu Kamus Bahasa Indonesia, Kamus Hukum, ensiklopedia, surat kabar dll.

Tempat penelitian merupakan lokasi dimana data maupun informasi tersebut diperoleh dalam rangka menyatakan kebenaran dari suatu penelitian agar nantinya berguna untuk mendukung tercapainya tujuan penelitian tersebut. Penentuan lokasi penelitian dilakukan secara sengaja. Lokasi penelitiannya di Pelaku Usaha UMKM Jawa Tengah, Dinas Koperasi UKM Jawa Tengah, konsumen, akademisi, dan praktisi.

Penelitian ini analisis dilakukan dengan 2 (dua) tahap: a) Tahap Pertama yang mendasarkan pada pendekatan 
doktrinal, analisis dilakukan dengan menggunakan metode analisis normatif kualitatif. Pada tahap ini peneliti melakukan inventarisasi aturan-aturan hukum yaitu menggambarkan hukum dengan logika hukum analisis kualitatif menggunakan metode logika deduktif. Data yang diperoleh (dikumpulkan) dalam penelitian ini dianalisis dengan mempergunakan teknik analisa data kualitatif. b) Tahap kedua yang mendasarkan pada pendekatan empiris, analisis yang dilakukan dengan menggunakan analisis kualitatif yang dilakukan menggunakan metode analisis interaktif (interaktif model of analisis). yaitu data yang dikumpulkan akan di analisa melalui 3 (tiga) tahap, yaitu mereduksi data, menyajikan data dan menarik kesimpulan. Model analisis seperti ini dilakukan suatu proses siklus antar tahap-tahap, sehingga data yang terkumpul akan berhubungan dengan satu sama lain dan benar-benar data yang mendukung penyusunan laporan penelitian. Ketiga tahap tersebut adalah: 1). Reduksi Data(data reduction), 2). Penyajian Data (data display) 3).Menarik kesimpulan (conclusion data).

\section{HASIL DAN PEMBAHASAN}

Pengembangan UMKM Digital di Masa Pandemi covid-19 di Jawa Tengah

Krisis ekonomi yang masif sedang melanda dunia termasuk di dalamnya Indonesia, banyak pelaku usaha khususnya pelaku yang terkena dampak adanya krisis ekonomi yang disebabkan oleh pandemi covid-19. perlu adanya inovasi dan kreatifitas dari pelaku UMKM agar usahanya dapat terus bertahan dan berkembang dalam situasi saat ini (Diah, 2020) .

Di Indonesia sudah terdapat UMKM yang mempersiapkan diri atas penggunaan teknologi digital dengan mulai tampak berjualan di media online. Namun masih banyak juga yang belum bersentuhan dengan internet, apalagi berjualan via online.
Berdasarkan Undang-Undang Nomor 20 Tahun 2008 tentang UMKM, usaha mikro adalah usaha produktif milik orang perorangan dan/atau badan usaha perorangan yang memenuhi kriteria usaha mikro sebagaimana diatur dalam UU tersebut. Usaha kecil adalah usaha ekonomi produktif yang berdiri sendiri, yang dilakukan oleh orang per orangan atau badan usaha yang bukan merupakan anak perusahaan atau bukan cabang perusahaan yang dimiliki, dikuasai, atau menjadi bagian baik langsung maupun tidak langsung dari usaha menengah atau usaha besar yang memenuhi kriteria usaha kecil sebagaimana dimaksud dalam UU tersebut (Elisabeth, 2021) .

Perekonomian daerah pada umumnya ditopang oleh kegiatan ekonomi berskala mikro, kecil dan menengah. Unit usaha yang masuk dalam kategori mikro, kecil dan menengah (UMKM) merupakan urat nadi perekonomian daerah dan nasional. UMKM merupakan pemain utama dalam kegiatan ekonomi di Indonesia (Hamid 2010) . Secara umum UMKM dalam perekonomian nasional memiliki peran: (1) sebagai pemeran utama dalam kegiatan ekonomi; (2) penyedia lapangan kerja terbesar, (3) pemain penting dalam pengembangan perekonomian lokal dan pemberdayaan masyarakat, (4) pencipta pasar baru dan sumber inovasi serta (5) kontribusinya terhadap neraca pembayaran. Selain itu, UMKM juga memiliki peran penting khususnya dalam perspektif kesempatan kerja dan sumber pendapatan bagi kelompok miskin, distribusi pendapatan dan pengurangan kemiskinan serta UMKM juga berperan dalam pebangunan ekonomi pedesaan. Pengembangan UMKM berbasis digital menjadi salah satu alternatif penyelamatan sektor UMKM di masa pandemi Covid-19. Meski demikian selama ini pemerintah dengan Kementerian Koperasi dan UKM telah berusaha mendorong terjadi transformasi digital. Pandemi Covid-19 telah membuat 
tumbuhnya ekosistem kewirausahaan digital.

Ada dua pilihan yang dipertimbangkan oleh masing-masing pelaku UMKM. Pilihan pertama adalah tetap bertahan dengan produk yang telah digeluti selama ini dengan memanfaatkan pasar digital dan diimbangi dengan penjualan secara konvensional. Pilihan kedua adalah tetap bertahan dengan produk baru yang paling dibutuhkan pasar di masa pandemi seperti: masker dan hand sanitizer. Mereka mengaku dua pilihan tersebut memiliki dampak yang berbeda dengan peluang yang seimbang. Pilihan pertama memungkinkan pelaku UMKM unutk belajar pemasaran digital sehingga dengan berjalannya waktu mereka belajar dan merencanakan bagaimana penjualan mereka meningkat. Hal ini memberikan keuantungan jangka panjang bagi pelaku UMKM adalah kesabaran dalam belajar pemasaran digital dan pemasukan omzet sedit karena bergantung pada pasar konvensional. Pilihan kedua memungkinkan pelaku UMKM memiliki peningkatan pendapatan, terlebih mereka menjual barang yang sangat dibutuhkan di masa pandemi covid-19. Namun terjadi persaingan usaha yang ketat terlebih keputusan membuat produk baru juga membutuhkan modal yang besar (Andayani, 2021).

Kewirausahaan digital merupakan bentuk bisnis yang memanfaatkan kecanggihan teknologi digital, baik proses hingga pada pemasaran produk dan jasa. Dengan kata lain, semua jenis usaha yang menjual produknya secara online baik menggunakan website atau aplikasi termasuk dalam ranah kewirausahaan digital.

Penggunaan aplikasi e-commerce dan pemanfaatan media sosial dalam pemasaran digital termasuk ranah kewirausahaan digital. Masa depan kewirausahaan digital bisa menjadi salah satu sektor yang akan banyak memberikan kontribusi positif pada penguatan perekonomian Indonesia. Hal ini dapat dilacak dari menguatnya peran teknologi informasi dalam dunia bisnis. Teknologi digital telah mengubah semua karakter dan sifat model kewirausahaan yang lebih berbasis digital.

Ada beberapa faktor yang mempengaruhi keputusan seseorang untuk berbelanja online shopping yakni: 1) Kenyamanan. Faktor ini sangat penting mengingat sebagian besar masyarakat mulai berusaha menghindari keramaian hingga berdesak-desakan saat berbelanja di pusatpusat perbelanjaan. Dengan demikian pilihan untuk berbelanja di online shopping menjadi alternatif baru yang bisa membuat lebih efektif. 2) Kelengkapan informasi. Hadirnya teknologi informasi membuat akses terhadap informasi begitu cepat dan mudah. Hal itu ditambah dengan banyaknya platform yang telah menyediakan beragam informasi, fitur rating dan review hingga memberikan ulasan tentang kualitas dan informasi sebuah produk. 3) Ketersediaan produk dan jasa. Hanya dengan mengakses website, masyarakat dapat dengan cepat mengetahui ketersediaan barang tanpa harus berkunjung ke toko tersebut. Hal ini juga dapat membantu calon pembeli yang berlokasi jauh dengan toko, dengan tidak perlu berkunjung namun tetap dapat membeli barang secara online. 4)Efisiensi Biaya dan Waktu. Beberapa website sering menawarkan kepada calon pembeli harga terbaik dengan membandingkan harga dibeberapa toko sekaligus. Perbandingan harga ini menjadi berarti bagi calon pembeli. Apalagi model online shopping dapat dilakukan dimana saja dan kapan saja.

Model kewirausahaan digital akan mendorong terciptanya inovasi baru sehingga dapat menciptakan ekosistem baru bagi UMKM yang bisa meningkatkan produktivitas dan kesejahteraan rakyat Indonesia. Selain itu dengan teknik ini para pelaku UMKM akan terus bermotivasi memanfaatkan teknologi dalam jaringan untuk memasarkan produknya. Eksesnya UMKM akan bisa segera beradaptasi dengan 
dunia digital yang kemudian dapat bersaing di kancah internasional.

Upaya pengembangan UMKM digital, salah satu alternatif yang dilakukan Kementrian Koperasi dan Usaha Kecil Menengah (Kemenkop UKM) ialah mengajak para inovator muda untuk mendukung program digitalisasi UMKM melalui program Pahlawan Digital UMKM. Program ini bertujuan agar selama masa pandemi Covid-19 ini, para pelaku UMKM tetap dapat bertahan dengan peningkatan penjualan dengan dukungan ekosistem digital. Sebab, hingga saat ini hanya sekitar 10-11 juta UMKM yang terhubung dengan ekosistem digital.

Kemenkop UKM memiliki strategi pengembangan digital UMKM melalui beberapa langkah, diantaranya peningkatan sumber daya manusia dengan mempersiapkan pelaku usaha UMKM agar kapasitasnya meningkat. Dikarenakan kualitas sumber daya manusia menjadi hal utama pengembangan UMKM di era digitalisasi. Sebab banyak pelaku UMKM mengakui menemui banyak kendala dalam penggunaan digitalisasi dan media sosial karena minimnya pengetahuan.

Pengembangan UMKM berbasis digital di Indonesia harus memperhatikan banyak hal terutama perihal konten kreatif. Sebab di era digital, konten merupakan pilar utama agar dapat bersaing di ranah digital. Tanpa konten kreatif sudah bisa dipastikan pengembangan UMKM berbasis digital sulit untuk membuahkan hasil yang signifikan. Dalam konteks ini perancangan konten kreatif harus diupayakan oleh pelaku UMKM baik secara mandiri maupun melalui berbagai pelatihan tambahan. Pelaku UMKM harus didorong untuk dapat memahami karakter dari dunia digital terutama media sosial. Dalam konten media sosial konten menjadi hal utama agar produk dan jasa yang ditampilkan bisa menarik perhatian para konsumen. Oleh sebab itu para pelaku usaha UMKM harus mengerti mengenai konten-konten kreatif dalam pemasaran digital. Beberapa studi telah menyebutkan bahwa konten kreatif dapat menarik perhatian yang tinggi dari para warganet.

Daya saing dapat diciptakan maupun ditingkatkan dengan penerapan strategi bersaing yang tepat, salah satunya dengan pengelolaan sumber daya secara efektif dan efisien. Penentuan strategi yang tepat harus disesuaikan dengan seluruh aktivitas dari fungsi perusahaan, sehingga akan menciptakan kinerja perusahaan sesuai dengan yang diharapkan bahkan lebih dan dapat menghasilkan nilai. Semua perusahaan, khususnya UKM bersaing untuk menjadi yang terdepan dalam era persaingan. Setiap UKM dituntut untuk memiliki daya saing yang tinggi, sehingga harus mulai memperbaiki diri. UKM yang memiliki daya saing tinggi ditandai dengan kemampuan sumber daya manusia (SDM) yang andal, penguasaan pengetahuan yang tinggi dan penguasaan perekonomian.

\section{Dampak dan Solusi dari Pengembangan UMKM Digital di Masa Pandemi Covid-19 di Jawa Tengah}

Permasalahan sekaligus tantangan pembangunan yang dihadapi pemerintah pusat dan daerah adalah kemiskinan, penggangguran dan kesenjangan. Pembangunan daerah adalah salah satu solusi untuk menjawab tantangan tersebut. Pembangunan daerah mempunyai tujuan utama yakni meningkatkan jumlah dan jenis peluang kerja bagi masyarakat. Untuk itu pemerintah dan masyarakat harus bersinergi an secara bersama-sama mengambil inisiatif dalam pembangunan daerah. Pemerintah daerah dituntut dan harus mampu menaksir potensi sumber daya yang ada untuk merancang dan membangun perekonomian daerah (Arsyad, 2010).

Ada 3 (tiga) kendala yang di hadapi oleh UMKM yaitu: Pertama, pelaku UMKM masih terkendala pada kapasitas produksi barang. Bahkan banyak UMKM yang gagal dipasar digital, karena tidak memenuhi permintaan pasar digital.Kedua, kualitas daya tahan pelaku UMKM yang belum 
merata. Dikarenakan di pasar digital ini para pelaku harus dapat bersaingan dengan perusahaan besar yang selama pandemi juga beralih menggunakan platform digital. Ketiga, diperlukan penguatan edukasi literasi digital dan penguatan sumber daya manusia para pelaku usaha UMKM (Suwarni,2019).

Berdasarkan hasil wawancara yang dilakukan terhadap UMKM di Jawa Tengah, maka ditemukan hasil bahwa secara umum pelaku UMKM terkena dampak baik secara langsung maupun tidak langsung. Adapun UMKM yang tidak mengalami permasalahan tersebut, adalah UMKM yang bergerak dibidang kesehatan, makanan dan pengolahan pangan. Hal ini menunjukkan, bahwa di masa pandemi covid-19 masyarakat tetap membutuhkan makanan untuk meningkatkan imun tubuh dan alatalat kesehatan. Bahkan saat adanya covid19, industri makanan menjadi barang yang paling di cari masyarakat untuk bekal di rumah (work from home) demikian juga dengan alat kesehatan mengalami lonjakan permintaan dan lonjakan harga.Hal ini adanya rumor beberapa alat kesehatan seperti masker, handsanitazer, alkohol dan lainnya akan langka di pasaran. Akibatnya masyarakat memborong alat-alat kesehatan yang ada di pasaran, yang mengakibatkan kelangkaan barang dan terjadinya kenaikan harga. Kondisi ini tidak berlangsung lama, karena pemerintah mampu mengendalikan pasar dan membuat kebijakan yang pro terhadap penyediaan alat-alat kesehatan bagi masyarakat, bahkan memberikan sumbangan secara gratis.

Dampak negatif masa pandemi covid-19 juga terkait dengan beberapa kebijakan dari pemerintah, antara lain:1) kebijakan work from home adanya sistem sift antar pegawai,2) pembatasan terhadap keramaian atau kerumunan 3) pembatasan buka toko, warung, kios dan pasar. Kebijakan pembatasan buka toko, warung, menyebabkan lesunya perekonomian dan masyarakat menjadi enggan belanja. Masyarakat hanya membeli barang-barang yang dinilai masih produktif. Kebijakan work from home menjadikan bagi pegawai kantoran menjadikan proses permintaan semakin menurun. Karena hampir semua pegawai kantoran bekerja dari rumah memiliki waktu utuk memasak buat keluarganya, sehingga mempu mengisi waktu buat keluarganya dan terhindar dari pelarangan terhadap kerumunan. Begitupun hari Sabtu dan Minggu yang biasanya wisata keluar kota, di saat pandemi covid-19 beberapa tempat wisata sepi bahkan tutup.

Pandemi covid-19 telah membuat menurunnya daya beli masyarakat. Dikarenakan publik telah mengurangi interaksi diluar ruangan untuk untuk menekan persebaran pandemi. Banyak konsumen yang kemudian menjaga jarak dan mengalihkan pembelian secara digital. Dampaknya banyak UMKM yang harus menurut usahanya karena menurunnya pembelian dan masih tergantung pada penjualan secara luar jaringan (offline). Sehingga beberapa sektor UMKM yang belum beradaptasi secara digital pada akhirnya sangat terdampak hingga menutup gerainya. Meski begitu pandemi covid-19 secara tidak langsung telah mendorong perubahan baru dalam langgam bisnis Indonesia (Purnomo, 2018). Perubahan tersebut yaitu beralihnya bisnis offline menuju bisnis digital yang dikenal juga sebagai fenomena kewirausahaan digital. Media sosial dan market place (perantara) dapat menjadi sebuah konsep untuk mempermudah pelaku UMKM mendapatkan akses pemasaran yang lebih luas.

Permasalahan yang paling mendasar dari kemampuan pelaku UMKM dalam memanfaatkan Teknologi Informatika (TI) sebagai sarana pendukung pengelolaan usahanya adalah persoalan kemampuan pengetahuan dan keterampilan (Skill), serta persoalan infrastuktur (Saleh, 2016).

Pemanfaatan digital marketing memiliki beberapa keunggulan, antara lain: Target bisa diatur sesuai demografi, domisili, gaya hidup, dan bahkan kebiasaan; 
Hasil cepat terlihat sehingga pemasar dapat melakukan tindakan koreksi atau perubahan apabila dirasa ada yang tidak sesuai;Biaya jauh lebih murah daripada pemasaran konvensional; Jangkauan lebih luas karena tidak terbatas geografis; Dapat diakses kapanpun tidak terbatas waktu; Hasil dapat diukur, misalnya jumlah pengunjung situs, jumlah konsumen yang melakukan pembelian online; Kampanye bisa dipersonalisasi; Bisa melakukan engagement atau meraih konsumen karena komunikasi terjadi secara langsung dan dua arah sehingga pelaku usaha membina relasi dan menumbuhkan kepercayaan konsumen. Digital marketing pun memiliki kelemahan, di antaranya: Mudah ditiru oleh pesaing; Dapat disalahgunakan oleh pihak-pihak tidak bertanggung jawab; Reputasi menjadi tidak baik ketika ada respon negatif; Belum semua orang menggunakan teknologi internet/digital.

Sosialisasi strategi digital marketing dalam bentuk pemanfaatan media sosial sangatlah penting karena dapat memberi pengetahuan kepada para pelaku UMKM mengenai cara maupun tahapan dalam memperluas jaringan konsumen melalui pemanfaatan media sosial dalam memasarkan produknya sehingga dapat meningkatkan keunggulan bersaing bagi UMKM itu sendiri.

Perubahan perilaku pemasaran dari konvensional ke digital tidak diimbangi oleh keberadaan pelaku UMKM yang menggunakan digital marketing, padahal UMKM dipercaya mampu memacu perekonomian Indonesia. Pemanfaatan konsep pemasaran berbasis teknologi digital menjadi harapan bagi UMKM untuk berkembang menjadi pusat kekuatan ekonomi. UMKM dapat menggunakan media sosial sebagai sarana digital marketing. Selain biaya yang murah dan tidak perlunya memiliki keahlian khusus dalam melakukan inisiasi awal, media sosial dianggap mampu untuk secara langsung meraih konsumen.
Para pelaku UMKM tertarik untuk menggunakan digital marketing dan memanfaatkan media sosial secara optimal, namun mereka menghadapi beberapa kendala. Kendala yang dihadapi contohnya adalah kurangnya pemahaman mengenai pentingnya digital marketing, kurangnya pengetahuan mengenai teknologi informasi dan komunikasi serta cara-cara penggunaan dan pemanfaatan media sosial yang baik, tidak sabar ingin segera mendapat hasil, serta kurangnya pemahaman untuk menciptakan "postingan" yang menarik. Perlu ada pelatihan-pelatihan yang lebih sering dilaksanakan untuk membangun kesadaran dan pemahaman mengenai digital marketing dan langkah-langkah yang harus dilakukan untuk membuat dan mengelola akun media sosial, materi yang disampaikan disesuaikan dengan kemampuan para peserta, serta adanya evaluasi lanjutan setelah kegiatan guna mengetahui apakah materi yang disampaikan betul-betul dipraktikkan.

Pelaku UMKM harus menumbuhkan keberanian untuk mencoba hal yang baru, berlaku profesional, dan sabar menunggu hasil sambil terus berkreasi.Dalam hal digital marketing dengan media sosial, pelaku UMKM sebaiknya:Membuat akun media sosial untuk usaha yang terpisah dari akun pribadi; Membuat nama akun yang sederhana, mudah diingat, menjelaskan tentang usahanya, dan memiliki nama yang sama dengan platform media sosial lain yang digunakan; Post secara berkala dan rutin, disesuaikan dengan "golden moment"; Usahakan setiap post selalu berkaitan dengan usaha; Buatlah tanda pagar (hashtag) unik yang mencirikan usaha kita dan gunakan itu di setiap post; Jawab segala pertanyaan yang ditanyakan oleh follower untuk menandakan bahwa akun aktif.

Keterbatasan raung gerak menjadi sumber utama permasalahan khususnya UMKM yang memiliki karakteristik diantaranya. 1) Produk berupa barang / jasa yang dikonsumsi langsung oleh masayarakat (consumer goods / jasa). 2) Kegiatan utama 
bersifat harian (daily basis). 3) Transaksi masih konvensional (tatap muka) dan menggunakan tunai (cash basis). 4) Pengelolaan keuangan masih sederhaa. 5) Pola pikir pemiliknya tradisional dan tingkat pendidikannya rendah. 6) Status usaha informal (tidak terdaftar, berlisensi dan terstandar produknya).

UMKM memliki beberapa kekuatan potensial yang merupakan andalan yang menjadi basis pengembangan pada masa yang akan datang adalah: a. penyediaan lapangan kerja peran industri kecil dalam penyerapan tenaga kerja patut diperhitungkan, diperkirakan mampu menyerap sampai dengan $50 \%$. tenaga kerja yang tersedia; b. Sumber wirausaha baru, keberadaan usaha kecil dan menengah selama ini terbukti dapat mendukung tumbuh kembangnya wirausaha baru ; c. memiliki segmen usaha pasar yang unik, melaksanakan manajemen sederhana dan fleksibel terhadap perubahan pasar; $d$. memanfaatkan sumber daya alam sekitar, industri kecil sebagian besar memanfaatkan limbah atau hasil dari industri sekitar, industri kecil sebagian besar e. memiliki potensi untuk berkembang. Berbagai upaya pembinaan yang dilaksanakan menunjukkan hasil yang menggambarkan bahwa industri kecil mampu untuk dikembangkan lebih lanjut dan mampu untuk mengembangkan sektor lain yang terkait.

Kelemahan yang sering juga menjadi faktor penghambat permasalahan dari UMKM terdiri dari 2 faktor : a. Faktor internal, merupakan masalah klasik dari UMKM diantaranya: a) masih terbatasnya kemampuan sumber daya manusia b) kendala pemasaran produk sebagian besar pengusaha Industri Kecil lebih memprioritaskan pada aspek produksi sedangkan fungsi-fungsi pemasaran kurang mampu dalam mengakseskannya, khususnya dalam informasi pasar dan jaringan pasar, sehingga sebagian hanya berfungsi sebagai tukang saja. c) kecenderungan konsumen yang belum mempercayai mutu produk Industri kecil. d) kendala permodalan usaha sebagain besar Industri Kecil memanfaatkan modal sendiri dalam jumlah yang relatif kecil. b. Faktor eksternal. Faktor eksternal merupakan masalah yang muncul dari pihak pengembang dan pembina UMKM. Misalnya solusi yang diberikan tidak tepat sasaran tidak adanya monitoring dan program yang tumpang tindih.

\section{KESIMPULAN}

Pengembangan UMKM digital di masa pandemi covid-19 di Jawa Tengah yaitu dengan adanya skema pengembangan UMKM digital dapat menjadi salah satu alternatif menyelamatkan pelaku usaha di tengah pandemi Covid-19. Pengembangan UMKM berbasis digital menjadi salah satu alternatif penyelamatan sektor UMKM di masa pandemi Covid-19.

Dampak dan solusi dari pengembangan UMKM digital di masa pandemi Covid-19 di Jawa Tengah adalah Banyak UMKM yang mengalami berbagai permasalahan seperti penurunan penjualan, permodalan, distribusi terhambat, kesulitan bahan baku, produksi menurun dan terjadinya banyak pemutusan hubungan kerja untuk pekerja dan buruh yang kemudian menjadi ancaman bagi perekonomian nasional. Solusinya perlu adanya inovasi dan kreatifitas dari pelaku UMKM agar usahanya dapat terus bertahan dan berkembang dengan model kewirausahaan digital akan mendorong terciptanya inovasi baru sehingga dapat menciptakan ekosistem baru bagi UMKM yang bisa meningkatkan produktivitas dan kesejahteraan rakyat Indonesia. Selain itu dengan teknik ini para pelaku UMKM akan terus bermotivasi memanfaatkan teknologi dalam jaringan untuk memasarkan produknya. 


\section{DAFTAR PUSTAKA}

Adi Kwartono, 2007, Analisis Usaha Kecil dan Menengah, Yogyakarta : Andi Offset.

Anggarani, 2014, Penguatan Sektor UMKM Sebagai Strategi Menghadapi MEA 2015, Jurnal Ekonomi 5 No.1,42-48

Anggia, M. N., \& Shihab, M. R. (2018). Strategi Media Sosial Untuk Pengembangan Umkm. Jurnal Terapan Teknologi Informasi, 2(2), 159-170.

Badan Pusat Statistik Indonesia, 2018, Potensi Usaha Mikro Kecil Sensus Ekonomi 2016, Jakarta : Badan Pusat Statistik.

Economic Comunity 2015, Jurnal $3^{\text {rd }}$ Economics and Busines Research Festival, 1013-1029

Harimurti Subanar, 2011, Management Usaha Kecil, BPFE, Yogyakarta.

Herdiansyah, 2010, Metodologi Penelitian Kualitatif, Jakarta : Salemba Humanika.

Irwansyah, 2011, Corporate and Marketing Communication, Jakarta : Puskombis Universitas Mercu Buana.

Sudarti I, 2014, Tantangan Usaha Kecil dan Menengah dalam Menghadapi ASEAN

Susilo, 2015.Strategi Meningkatkan Daya Saing UMKM dalam Menghadapi Implementasi CAFTA dan MEA, Buletin Ekonomi Vol.8 No.70-170.

Undang-Undang Dasar Negara Republik Indonesia Tahun 1945.

KUHPerdata

Undang-Undang No. 20 Tahun 2008 tentang Usaha Mikro, Kecil dan Menengah

Peraturan Pemerintah No. 7 Tahun 2021 tentang Kemudahan, Pelindungan, dan Pemberdayaan Koperasi dan Usaha Mikro, Kecil dan Menengah. 